University of Wollongong

Research Online

Faculty of Engineering - Papers (Archive)

Faculty of Engineering and Information

Sciences

$1-6-2005$

\title{
Addressing the Geotechnical Challenges Posed by Soft Clays
}

Buddhima Indraratna

University of Wollongong, indra@uow.edu.au

Follow this and additional works at: https://ro.uow.edu.au/engpapers

Part of the Engineering Commons

https://ro.uow.edu.au/engpapers/110

\section{Recommended Citation}

Indraratna, Buddhima: Addressing the Geotechnical Challenges Posed by Soft Clays 2005.

https://ro.uow.edu.au/engpapers/110

Research Online is the open access institutional repository for the University of Wollongong. For further information contact the UOW Library: research-pubs@uow.edu.au 


\section{Addressing the Geotechnical Challenges Posed by Soft Clays}

\section{Buddhima Indraratna, Guest Editor}

Professor of Civil Engineering, Univ. of Wollongong, Wollongong City, NSW 2522, Australia.

This Special Issue of the Int. J. Geomech. on soft clay engineering and soft clay improvement is a result of discussion among various colleagues during the Geo-2000 Conference in Melbourne, where the need for a Special Issue on soft clay engineering and improvement was raised. The papers contributed to this Special Issue are selected to reflect the latest developments relating to soft clay engineering and improvement, and address research and applications in many places around the world (e.g., Australia, Finland, The Netherlands, Norway, Singapore, United Kingdom, and the United States). This Special Issue covers a variety of aspects for soft clay engineering and improvement, including constitutive modeling, numerical and analytical methods, design parameters, field and laboratory testing, and case studies.

The issue begins with an invited introduction by Chandra S. Desai, of the University of Arizona, titled "Constitutive Modeling for Geologic Materials: Significance and Directions.” It draws our attention to the importance of developing appropriate constitutive models for solving geotechnical problems. Prof. Desai presents a brief but comprehensive overview of the available constitutive models for soft soils, and describes briefly the recently developed unified model based on the disturbed state concept (DSC).

In their study on "The Effect of Anisotropy and Destructuration on the Behavior of Murro Test Embankment," M. Karstunen, H. Krenn, and S. Wheeler of University of Glasgow, M. Koskinen (Helsinki University of Technology), and R. Zentar (Ecole des Mines de Douai) investigate, further, the importance of adopting proper constitutive models for simulating the behavior of soft soils. The paper demonstrates the influence of anisotropy and destructuration on the behavior of soft clay soils using the finiteelement analysis and three different constitutive models that have been recently developed to account for anisotropy and destructuration. The study also compares the results of numerical analyses with field observations for a test embankment constructed at Murro, Finland.

"Uplift Phenomenon: Model, Validation, and Design," by M. Van, A. Koelewijn, and F. Barends, of Delft University of Technology, proposes a new analytical stability design method for uplift-induced slope failure as a result of high water pressures in sand layers below soft topsoil layers. The study verifies the results of the new proposed design method by conducting appropriate geocentrifuge testing, a full-scale field test, and finite-element numerical modeling. Furthermore, the authors compare the results of the new design method with four existing methods for ten Dutch polder dikes in The Netherlands. The new method is now accepted in the Dutch national guidelines for dike design.

The study on "Loads on Braced Excavations in Soft Clay," by K. Karlsrud and L. Andresen of Norwegian Geotechnical Insti- tute, uses finite-element analysis to demonstrate the importance of soil strength and soil depth of normally consolidated clay on the earth pressures, strut loads, and bending moments of a strutted sheet pile wall. The paper compares the results of three different FEM soil models, namely, anisotropic nonlinear, isotropic linear elastic-plastic, and beam-on-spring. The authors also examine the factors affecting loads on braced excavations in soft clay by carrying out a parametric study.

In the paper "Analytical and Numerical Modeling of Soft Soil Stabilized by PVD Incorporating Vacuum Preloading," B. Indraratna, I. Sathananthan, and C. Rujikiatkamjorn of University of Wollongong, and A. Balasubramaniam (Griffith University) describe the analytical and numerical modeling of soft clay stabilized by prefabricated vertical drains (PVDs) incorporating vacuum pressure for both axisymmetric and plane strain conditions. Through a set of new equations incorporated in finiteelement analysis, the authors examine the effect of the magnitude and distribution of vacuum pressure on soft clay consolidation. The paper also describes the performance of a full-scale test embankment constructed on soft Bangkok clay using the numerical analysis.

"An experimental study of the behavior of a lumpy fill," by R. Robinson, T. Tan, G. Dasari, C. Leung, and A. Vijayakumar of the National University of Singapore evaluates the use of dredged and excavated lumpy clay fills as a fill material, as an alternative to the cost imported sand. The paper describes the behavior of cubical clay lumps under different consolidation pressures by means of laboratory tests. The study also investigates the influence of the size of lumps, initial packing arrangement, and degree of swelling on the behavior of the lumpy clay fills.

In their contribution "Reinforced Soil Using Cohesive Fill and Electrokinetic Geosynthetics (EKG)," R. Pugh (GEOCISA), S. Glendinning, and C. Jones of University of Newcastle describe the use of a polymeric geosynthetic material (electrokinetic geosynthetic, EKG) and wet cohesive fill to construct an earthreinforced wall. The paper describes the concept of the EKG and presents the design procedures, construction details, and method of analysis of a full-scale earth wall built with the EKG technology. The paper also introduces a design method, based on an electroosmotic treatment process, for estimating the change in undrained shear strength of clay with time.

"Soft Sediments: Wave-Based Characterization," by K. Klein (University of Toronto) and C. Santamarina (Georgia Institute of Technology), presents an experimental study on the behavior of soft sediments involving kaolinite-electrolyte mixtures. The paper describes two types of tests for characterizing the behavior of soft sediments, namely, index tests and wave-based techniques. The authors also investigate the factors affecting the mechanical response of soft sediments.

"Estimation of Degree of Consolidation for Vacuum Preloading Projects," by J. Chu (Nanyang Technical University) and S. Yan (Tianjin University), suggests a method for estimating the 
degree of consolidation of vacuum-preloaded soils using pore water pressure data rather than settlement data. The paper verifies the suggested pore pressure method by comparing its results with those obtained using the settlement data for three case studies of vacuum-preloading projects. The study also includes an assessment of factors affecting the degree of consolidation.

The nine papers included in this Special Issue contain an excellent mix of soft soil engineering topics, and all papers have been peer-reviewed according to ASCE guidelines to maintain high standards. The efforts of all reviewers are gratefully acknowledged. The assistance of Prof. Chandra Desai (Editor-inChief, University of Arizona), Dr. Mohamed Shahin (University of Wollongong), and the staff of ASCE's Journals Department during the entire period of review, editing, and publishing is gratefully appreciated. This Special Issue will provide a comprehensive reference volume to a number of problems in the field of soft clay engineering and soft clay improvement, and will be of immense benefit for researchers and practicing engineers. 